\title{
Embedded Local Wisdom to Education: The Pappaseng Local Wisdom to Improve Students' Leadership Attitude
}

\author{
Dian Ekawati ${ }^{1}$, Djono $^{2}$, and Sudiyanto ${ }^{3}$ \\ \{dian.ekha99@student.uns.ac.id ${ }^{1}$,djono_sk@yahoo.com², \& soeddie.fkipuns@gmail.com³ \\ 1,2,3 Master of Historical Education, Universitas Sebelas Maret, Surakarta, Indonesia
}

\begin{abstract}
Local wisdom comes from cultural values that are used to regulate people's lives. Indonesia has a lot of local wisdom that can be embedded in the learning process. One of the local wisdom from Makassar region of South Sulawesi province is Pappaseng the classical Bugis literature. The contents of pappaseng in the form of a Bugis Makassar language manuscript include providing guidance to the community to become human beings with good character in the dimensions of heart, mind, body, feeling, and intention, both as leaders and members of the community. The purpose of this study was to investigate the leadership values contained in pappaseng and the possibility of embedding these values in historical learning to improve student leadership attitudes. The qualitative approach and hermeneutic methods were used in this study. Data collection used literature research on Lontaraq Pappaseng text and documentation studies. The results of the study showed that there were leadership values contained in pappaseng, namely ingenuity, honesty, bravery, expediency, and good leadership. The leadership values contained in the pappaseng, if embedded in historical learning are thought to improve student leadership attitudes. The implication of this finding was that further research is needed to prove this allegation.
\end{abstract}

Keywords: local wisdom, pappaseng, leadership values

\section{INTRODUCTION}

Local wisdom is defined as the noble values that are followed and maintained by certain communities that aim to protect and preserve the local culture and environment[1]. Local wisdom comes from cultural values that are used to regulate people's lives. The human life order is related to its interaction with God, nature, and community. This means that there are norms, rules, and ethics that must be followed by humans. Local wisdom has been used by our ancestors in the Indonesian archipelago for a long time to wisely regulate life. Positive values of Indonesian culture must be developed to be applied by modern society. Education developed in Indonesia must be based on Indonesian cultural values. The development of modernization of education is not to eliminate the positive values that have been owned by Indonesians[1], [2]. Rather, it is to preserve cultural values that are being abandoned. 
Many Indonesian researchers conducted research on local wisdom from various regions in Indonesia. Like the local wisdom of Sarabakawa in Kalimantan which is used as a context for physics learning [3], [4],the local wisdom of the Kampung Naga, West Java is used as a context for learning physics[1], [5] the local wisdom of the Minangkabau community is used to prevent human trafficking [6], or study of local wisdom behind traditional Indonesian food, namely NasiTumpeng.

It is believed that preserving local wisdom in the teaching and learning process is a must [1]. Research has proven that by instilling local wisdom in learning can increase interest[6], [7], attitude[8], character[9]tolerance[10]and national identity[11]. Indonesia has a lot of local wisdom potential that can be planted during learning, one of which is the potential of local wisdom from the Makassar region of South Sulawesi province, namely Pappaseng.

In South Sulawesi, in the past, there was a tradition of writing texts in Makassar, Bugis, Arabic and Roman languages or sometimes combinations. Initially, Bugis and Makassar scripts were written in lontaraq leaves, which has become the term used for most of the manuscripts in this area. The Lontaraq text illustrates the richness of Bugis culture which contains many philosophical teachings related to various aspects of life which are inherited from the ancestors. One of the local wisdom that is part of Lontaraq is Pappaseng[2], [12].

Pappaseng is one of the many local pearls of wisdom inherited from ancestors. Pappaseng contains advice on concepts and structures of life that are good for the community. In the pappaseng, there are instructions about religious moral values, good governance, the value of ethical education and matters relating to the order of life. Pappaseng is used as a foundation in forming a civilized, safe and peaceful society [2]

The meaning of pappaseng in Bugis language has the same meaning as advice. Pappaseng is a form of classical Bugis literature that is still lived up to now by the people. In Bugis culture, Pappaseng has important role not just expressions that have no meaning but emphasize necessity and abstinence. The contents of pappaseng or pappasang in the form of a Bugis Makassar language manuscript include providing guidance to the community to become human beings with good character in the dimensions of heart, mind, body, feeling, and intention, both as leaders and members of the community [13].

The messages in pappaseng are rich in pedagogical nuances, especially human character education, which includes messages to be good leaders, how to maintain a good heart and ethics, honesty in all aspects of life. It is hoped that the integration of various educational values contained in the Lontaraq will be a step or part of educational efforts that will make students able to handle various life problems in the era of globalization [2], [13]. Therefore, the purpose of this study was to investigate the values contained in pappaseng and the possibility of embedding these values in historical learning to improve student leadership attitudes.

\section{METHOD}

This study used a qualitative approach and hermeneutic methods and content analysis. Data collection used literature research on Lontaraq Pappaseng/Pappasang text and documentation studies. The text refers to the Lontaraq documents, oral history and the results of previous studies. The data sources used are the Lontaraq manuscripts that have been collected by philologists and Bugis humanists who contain various advices from Bugis ancestors. This study focuses on the study of texts that describe the value characteristics or attitudes related to leadership. The texts reviewed as research objects are pappaseng texts that have been collected and compiled into a collection of pappaseng books. The formulation of 
the problem in this study is how the leadership values according to lontaraq pappaseng/pappasang and how the possibility of instilling these values in historical learning to improve student leadership attitudes

\section{RESULTS AND DISCUSSION}

\subsection{Form of Pappaseng local wisdom}

Pappaseng, as regional literature and cultural results that are full of values and meaning, should be reappointed and introduced to students. This Pappaseng is expressed in several forms [14]. Descriptions of the form of pappaseng are presented in Table 1

Table 1. Form of Pappaseng Local Wisdom

\begin{tabular}{|c|c|c|}
\hline No & Form & Characteristics \\
\hline 1 & $\begin{array}{l}\text { Pappaseng in } \\
\text { the form } \\
\text { ofélong }\end{array}$ & $\begin{array}{l}\text { In Bugis language Elong can be interpreted as singing or poetry, but } \\
\text { pappaseng in elong form is rarely found because it is usually delivered by } \\
\text { poets or poets. The characteristics of Pappaseng Elong are: } \\
\text { a. Élong consists of two, three to five lines. But there are also lots to tens of } \\
\text { lines. } \\
\text { b. Élong in three has tribal patterns. The tribal pattern in question is the first } \\
\text { array consisting of } 8 \text { syllables, the second } 7 \text { syllables and the third } 6 \\
\text { syllables. } \\
\text { c. Élong which contains a complete understanding does not always consist } \\
\text { of several stanzas }\end{array}$ \\
\hline 2 & $\begin{array}{l}\text { Pappaseng in } \\
\text { the form } \\
\text { ofwarekkada }\end{array}$ & $\begin{array}{l}\text { Warekkada can be interpreted as an expression or proverb. In another sense, } \\
\text { warekkada can be said to be words that specifically convey a purpose that has } \\
\text { a figurative meaning }\end{array}$ \\
\hline 3 & $\begin{array}{l}\text { Pappaseng in } \\
\text { the form of } \\
\text { conversation }\end{array}$ & $\begin{array}{l}\text { Pappaseng delivered in the form of conversation is divided into two types. } \\
\text { First, the pappaseng delivered monologically and secondly, the pappaseng } \\
\text { delivered in dialogue. Pappaseng delivered in monologue is delivered by itself, } \\
\text { while what is conveyed in a dialogue is a conversation between two people. } \\
\text { Pappaseng in the form of a monologue is generally conveyed by philosophers. } \\
\text { While dialogue is usually carried out by the king and the king's advisor }\end{array}$ \\
\hline
\end{tabular}

As a cultural product, pappaseng contains values that are useful in life. Inside contained ideas, noble thoughts, experiences, considerations of good and bad traits and so on. Some descriptions of the values contained in pappaseng are: Scholarity, Honesty, Loyalty, Courage, Wisdom, Work Ethics, Mutual Cooperation, Firmness, Shame, Solidarity, Religious, Unity, Harmony, and Deliberation [14].

\subsection{Leadership values contained in Pappaseng}

Building a community requires the role of traditional culture. The presence of this traditional culture is not only to face the challenges that exist, but also as the meaning of life. The pappaseng quotations presented in this paper are texts that contain values in leadership. In pappaseng there are many values related to everyday life and even to the problems of government. but what will be discussed is only those related to leadership values [2].

A story about the leadership found in Pappaseng namely, in ancient times Datu Soppeng La Manussa to the leadership of Akkarangeng, the people experienced starvation caused by a long dry season. The results of the investigation into the disaster showed that no royal official had done things that were considered detrimental to the people. After being tracked for a long time, finally Datu Soppeng remembered that he had taken something from someone else's field and saved it. Datu Soppeng considered that it might be the cause of the disaster in the 
country. As a redeemer of guilt he imposed a sacrifice by slaughtering a buffalo and distributing the meat to the people and announcing and acknowledging that he had made a mistake. This is also done as an effort to ask the public whether there is someone who has lost ownership of the items that have been stored. The Pappaseng story above shows that the leadership model of the Makassar Bugis king has made mankind the centre that determines their cultural life [2].

The text of pappaseng on lontarak, if studied more deeply to understand the implicit and explicit meaning in the text, a philosophy of life for the ancestors of the Bugis community will be found. This philosophy is the basis of various values of bugis community behaviour in the past. In Table 2, pappaseng is presented with a study of the meaning and values contained [14].

Table 2. Leadership values contained in the Pappaseng Text

\begin{tabular}{|c|c|c|c|}
\hline No & Pappaseng Texts & Pappaseng text translation & $\begin{array}{c}\text { Leadership } \\
\text { Values }\end{array}$ \\
\hline 1 & $\begin{array}{l}\text { Sininna gauk- é mattarattéppi } \\
\text { namadécéng. Issengi maja-é } \\
\text { mutettangi. Pénessaiwi jaji-é. Itatoi } \\
\text { tekkuaé, panessai kuwa-é, issengi } \\
\text { majékko-é. Pénessai malempuk-é }\end{array}$ & $\begin{array}{l}\text { All of our actions must be orderly, up } \\
\text { and down in order to get good } \\
\text { (success). What is bad is taken away, } \\
\text { what is considered good is what is } \\
\text { done. Estimate that hasn't happened } \\
\text { yet and know what happened. It must } \\
\text { also be seen which are impossible and } \\
\text { which are possible. Also know which } \\
\text { ones are bad and which ones are } \\
\text { good. }\end{array}$ & Ingenuity \\
\hline 2 & 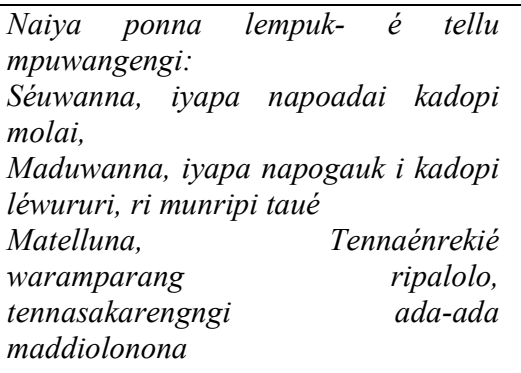 & $\begin{array}{l}\text { There are three types of honesty } \\
\text { which are the basis of honesty: } \\
\text { First, something is said to be able to } \\
\text { be done. Second, it is done if it is } \\
\text { able to bear the risk. Third, do not } \\
\text { accept bribes, do not deny / deny the } \\
\text { words that have been said before }\end{array}$ & Honesty \\
\hline 3 & $\begin{array}{l}\text { Akguruwi gaukna tau waranié énrengé } \\
\text { ampéna. Apak iya gaukna towaranié } \\
\text { seppuloi uwangenna naséuwamua } \\
\text { jakna, jajini aséra décénna. Nasaba } \\
\text { iyanaro nariaseng jakna séddié } \\
\text { malamoi naola amaténgngeng. } \\
\text { Naékiya mau tau péllorengngé } \\
\text { matémuto, napak déssa temmaténa } \\
\text { sininna makkényawaé. Naiyya décénna } \\
\text { asérae: } \\
\text { a) Tettakinik napoléi karéba maja } \\
\text { karéba madécéng. jampangiwi karéba } \\
\text { b) Dékna jaékiya } \\
\text { naéngkalingae, } \\
\text { napaesilaonggi sennang ati } \\
\text { pikkirik madécéng. } \\
\text { c) Temmémtauni ripariolo }\end{array}$ & $\begin{array}{l}\text { Learn courageous behavior. There } \\
\text { are ten kinds of brave behavior. Only } \\
\text { one bad thing. But nine of his } \\
\text { kindness. He is said to be bad } \\
\text { because it is easily threatened by } \\
\text { death. But the cowardly person did } \\
\text { not escape death. Because every } \\
\text { animate person must die. The } \\
\text { behavior of a brave person } \\
\text { a) Not surprised to hear good news or } \\
\text { bad news } \\
\text { b) Not panic about receiving the } \\
\text { news he heard but received calmly } \\
\text { and with a healthy mind } \\
\text { c) Not afraid to come forward } \\
\text { d) Not afraid to be shown behind } \\
\text { e) No fear of seeing the enemy }\end{array}$ & Bravery \\
\hline
\end{tabular}




\begin{tabular}{llll}
\hline No & \multicolumn{1}{c}{ Pappaseng Texts } & Pappaseng text translation & $\begin{array}{c}\text { Leadership } \\
\text { Values }\end{array}$ \\
\hline & & & \\
d) Temmémtauni riparimunri & f) Become a shield for the country & \\
e) Tettéyai mita bali & g) Diligently carry out obligations \\
f) Rialai passappo ri wanuaé & h) Become a fortress against antidote & \\
g) Matnuluk i pajajai passirong & i) How to respect fellow human & \\
h) Rialai paddebang tomawatang & beings & \\
i) Masiriktoi, & & \\
& ripadanna tau & &
\end{tabular}

$4 \quad$ Makkedai Tomaccaé Ri Luwuk: Iyana wakkeda olakku uakkolaki, de upaliwuriwi tau-é narekko tenna kadoiwi liwurriwi. Déto upawawai tauéri tengngélona.

Déto upatiwiri tau-é tennaullewe. Déto upakennaiwi tau-é dua dodosok. Déto upattenniwi dua alu
Tomaccaé ri Luwuk said:

What I meant by the measure I used was measuring,

I will not tell someone to sleep in a place he does not like. I didn't give a burden that he didn't like. I also did not tell someone who was suitable for two heavy loads. I didn't say it too. Nor did I tell him to do two jobs at the same time

Four things that damage the village Good leader (area):

a) Greed, eliminate shame.

b) Violence, eliminating feelings of love in the village

c) Fraud decides family relationships between citizens

d) Be careful, keep doing things right in the village

If greed is used as capital, everything will be released. If fraud is used as capital, the difficulty is the result. If honesty is used as capital, it will foster a sense of trust and will bring peace. If fairness is used as capital, it will produce sympathy and bring safety

These values indicate that a leader must have good temperament and can be an example for the people he leads. A leader should always say with gentle words, believe in fellow human beings, think positively, behave well and fear Allah. It is desirable that a leader does not abandon his skills and honesty in order to always act well and be full of responsibility for the will that is imposed on him. Thus, the people he leads will feel calm and serene[2]. These skills are needed in the leadership and the 21 st century era [15]

In pappaseng in every pattern of behavior of leaders everyday will always be maintained behavior, and respected in the midst of the community. Conversely when someone does not heed and underestimate it, he will bear severe sanctions, his name will not be trusted and have a low social status, so it is very difficult to adapt and interact well in the community around him, not even his life will often deteriorate [2], [14].

Indonesian researchers have paid attention to pappaseng, as evidenced by a number of studies that examined pappaseng and its meanings, such as the study of pappaseng texts as teaching material [2], study of Bugis symbols found in pappaseng[16], study of the 
philosophical meaning of the life of the Bugis community in pappaseng[17], study of the national character contained in pappaseng[18],and messages of the Holy Qur'an found in pappaseng[19].

Pappasengwhich contains a lot of values, especially leadership values, will be a good learning resource for students. According to the results of research by researchers, the attitudes and values of student leadership can improve through several things, such as by using leadership literacy in learning to increase student struggling[21], teach students to be aware of their responsibilities [22], involving students with practice in the community, stimulating students with various literature and discussions about leadership [23]. With the existence of various evidence of literature support and leadership values contained in the pappaseng, the embedding of pappaseng local wisdom in historical learning is thought to improve student leadership attitudes [24]

\section{CONCLUSION}

The contents of pappaseng in the form of a Bugis Makassar language manuscript include providing guidance to the community to become human beings with good character in the dimensions of heart, mind, body, feeling, and intention, both as leaders and members of the community. The results of the study showed that there were leadership values contained in pappaseng, namely ingenuity, honesty, bravery, expediency, and good leadership. The leadership values contained in the pappaseng, if embedded in historical learning are thought to improve student leadership attitudes. The implication of this finding was that further research is needed to prove this allegation.

\section{REFERENCES}

[1] Nasrudin D Rochman C and Muhyiddin A, 2018 Physics Phenomena on Housing Architecture in Kampung Naga IOP Conf. Ser. Mater. Sci. Eng.288, 012044.

[2] Abbas I, 2013 Criteria of Ideal Leadership by Lontaraq a Study for Learning Materials of Social Int. J. Hist. Educ. 26, 2 p. 169-170.

[3] Hartini S and Dewantara D, 2017 The Effectiveness of P hysics Learning Material Based o n South Kalimantan Local Wisdom AIP Conf. Proc.1868, 070006.

[4] Hartini S Firdausi S Misbah and Sulaeman N F, 2018 The Development of Physics Teaching Materials Based on Local Wisdom to Train Saraba Kawa Characters $J$. Pendidik. IPA Indones. 7, 2 p. 130-137.

[5] Nasrudin D Rochman C Yuningsih E K Y Helsy I and Hasanah A, 2018 Chemical physics in the process of making handicraft Pandanus tectorius and its local wisdom IOP Conf. Ser. Mater. Sci. Eng.434, 012019.

[6] Shidiq A S, 2016 Pembelajaran Sains Kimia Berbasis Etnosains Untuk Meningkatkan Minat Dan Prestasi Belajar Siswa in Seminar Nasional Kimia dan Pendidikan Kimia VIII p. 227-236.

[7] Yamtinah S Masykuri M Ashadi M and Shidiq A, 2017 An Analysis of Students' Science Process Skills in Hydrolysis Subject Matter Using Testlet Instrument in Proceedings of the International Conference on Teacher Training and Education 2017 (ICTTE 2017)158, Ictte p. 101-110.

[8] Dwianto A Wilujeng I Prasetyo Z K and Suryadarma I G P, 2017 The Development of Science Domain Based Learning Tool Which Is Integrated With Local Wisdom to Improve Science Process Skill And Scientific Attitude J. Pendidik. IPA Indones.6, 1 p. $23-31$. 
[9] Permatasari I and Hakam K A, 2018 The Development of Character Education Based on Sundanese Local Wisdom IOP Conf. Ser. Earth Environ. Sci.145, 012124 p. 1-5.

[10] Shernoff D J Sinha S Bressler D M and Ginsburg L, 2017 Assessing teacher education and professional development needs for the implementation of integrated approaches to STEM education Int. J. STEM Educ.4, 1 p. 1-16.

[11] Khoeriyah N Warto and Sariyatun, 2018 Learning history integrated local wisdom values "babad Banyumas" to build a student's national identity SHS Web Conf.42, 00091 p. 1-6.

[12] Teng M B A, 2018 Open Access Social Messages of "Kajaolaliddong" in Living Harmony : A Historical Perspective Am. J. Humanit. Soc. Sci. Res. 07 p. 39-44.

[13] Iswary E, 2012 Orientasi pendidikan karakter berbasis kearifan lokal Makassar: penguatan peran bahasa ibu menuju good society in Kearifan Lokal dan Pendidikan Karakter.

[14] Sikki M Hakim Z Mahmud and Sande J S, 1991 Nilai-nilai Budaya dalam Susastra Daerah Sulawesi Selatan Jakarta: Pusat Pembinaan dan Pengembangan Bahasa Departemen Pendidikan dan Kebudayaan.

[15] Shidiq A S and Yamtinah S, 2019 Pre-service chemistry teachers ' attitudes and attributes toward the twenty-first century skills J. Phys. Conf. Ser.1157, 042014 p. 1-8.

[16] Kamaluddin, 2017 the Use of Buginese Ancestors' Messages Pemakaian Simbol-Simbol Bugis Dalam Pappaseng To-Riolo J. Noken Ilmu-Ilmu Sos.3, 1 p. 11.

[17] Tundreng S Emzir E and Lustyantie N, 2018 Life Philosophy Values of Buginese Makassarese in the Novel PULAU by Aspar Paturursi (A Genetic Structural Review) Int. J. Lang. Lit.5, 2 p. 98-103.

[18] Dafirah, 2018 Moral Values " Paseng / Pappaseng " In The Formation of National Character Based on Local Wisdom J. Humanit. Soc. Sci.23, 2 p. 11-15.

[19] Sugirma, 2017 Mengungkap Pesan-Pesan Al-Quran Melalui Petuah Bugis "Pappaseng To Riyolo" J. Soc. Res.2, 1 p. 37-55.

[20] Ismail A Santoso A and Sunoto, 2018 Vocabulary Options of Power Experiential Value of Bugis Female J. Intensive Stud. Lang. Lit. Art, Cult.2, 1 p. 54-61.

[21] Taylor R T, 2015 Using Literacy Leadership to Improve the Achievement of Struggling Students Middle Sch. J.36, 1 p. 26-31.

[22] Pickering M M, 1921 How Best to Prepare Students for Leadership Am. J. Nurs.21, 9 p. 601.

[23] Eacott S, 2012 Introducing undergraduate students to school leadership concepts $J$. Educ. Adm.50, 2 p. 159-172.

[24] K. Saddhono, "Integrating Culture in Indonesian Language Learning for Foreign Speakers at Indonesian Universities." J. of Lang. and Lit. vol. 6 no.2 pp. 349-353, 2015 